\title{
Cultural Method Considerations for Integrated Weed Management in Agronomic Crops ${ }^{1}$
}

\author{
Prasanna Kharel, Pratap Devkota, and Greg MacDonald ${ }^{2}$
}

\section{Introduction}

With the increasing issue of herbicide-resistant weeds, adopting cultural practices that aid in weed suppression is beneficial. This article provides growers with information on various cultural methods to increase weed control in their fields, reduce herbicide inputs, and contribute to integrated weed management.

Cultural weed control methods involve increasing the competitive ability of crops against weeds. Cultural methods do not necessarily provide complete weed control but aid in weed suppression by providing a competitive advantage to crops in capturing light, moisture, nutrients, and physical space. Implementing appropriate cultural methods in a timely manner can reduce weed density, weed competition, and number of herbicide applications, mitigate herbicide resistance by reducing selection pressure, and contribute to integrated weed management. Potential cultural methods and their implications for weed management in major agronomic crops in Florida are discussed below.

\section{Crop Rotation}

Rotating crops that differ in planting date, management requirement, competitive ability, and harvest date disrupts weeds that are adapted to a particular cropping system and reduces weed pressure. Rotating legume crops (e.g., peanut or soybean) with non-legume crops (e.g., cotton or corn) in a timely manner, rather than growing crops with similar characteristics, can contribute to long-term weed management. For instance, peanut can be rotated with cotton or sod-based bahiagrass in Florida. In addition, herbicides with different modes of action can be utilized in rotational crops and prevent establishment of problematic weed species. Crop rotation and diversifying herbicide mode of action also reduce selection pressure and prevent the development of resistance to the primary herbicides used in a particular cropping system.

\section{Cover Crops}

In addition to soil moisture conservation and many other benefits, cover crops aid in weed suppression. The level of weed suppression from cover crops varies by species and is directly related to biomass production. Higher-biomassproducing cover crops such as cereal rye can suppress weeds better than low-biomass-producing cover crops such as clover. Likewise, the use of allelopathic cover crops such as mustard species, buckwheat, rye, or oats can be advantageous for weed suppression. In addition to direct physical weed suppression, planting leguminous cover crops (e.g., vetch or clover) before non-leguminous crops (e.g., corn and cotton) can provide nitrogen for early crop establishment and crop canopy development, and contribute indirectly to weed suppression.

1. This document is SS-AGR-451, one of a series of the Agronomy Department, UF/IFAS Extension. Original publication date May 2021. Visit the EDIS website at https://edis.ifas.ufl.edu for the currently supported version of this publication.

2. Prasanna Kharel, graduate research asssistant, UF/IFAS West Florida Research and Education Center; Pratap Devkota, assistant professor, weed science, UF/IFAS West Florida REC; and Gregory MacDonald, professor, weed science, Agronomy Department; UF/IFAS Extension, Gainesville, FL 32611.

All chemicals should be used in accordance with directions on the manufacturer's label.

The Institute of Food and Agricultural Sciences (IFAS) is an Equal Opportunity Institution authorized to provide research, educational information and other services only to individuals and institutions that function with non-discrimination with respect to race, creed, color, religion, age, disability, sex, sexual orientation, marital status, national origin, political opinions or affiliations. For more information on obtaining other UF/IFAS Extension publications, contact your county's UF/IFAS Extension office. U.S. Department of Agriculture, UF/IFAS Extension Service, University of Florida, IFAS, Florida A \& M University Cooperative Extension Program, and Boards of County Commissioners Cooperating. Nick T. Place, dean for UF/IFAS Extension. 
Cover crops should be planted at proper seeding rates to ensure dense stands and higher biomass. Additionally, cover crops should be irrigated, fertilized, and limed (if required) to produce healthy stands that can outcompete weeds. An important consideration with cover crops is appropriate termination timing. The cover crops should be terminated at the right growth stage so they do not become weeds by competing with the agronomic crop. Normally, cover crops are terminated after they attain maximum biomass and before they produce seed. Terminating cover crops a few weeks before crop planting helps in retaining cover crop residue during the crop season and can result in greater suppression of early-season weeds.

\section{Use of Competitive Cultivars}

Canopy architecture of a crop is related to its competitive ability against weeds. Crops with rapid growth and quicker canopy closure characteristics have higher weed suppression potential. For example, corn varieties with horizontal leaf architecture provide better weed suppression than varieties with upright leaf architecture (Sankula et al. 2004). Peanut varieties can differ greatly in morphological characteristics such as canopy width and height; these differences can influence their competitive ability with weeds. Overall, vigorously growing crops are beneficial because they shade row spacing earlier and prevent weed establishment.

\section{Planting Date}

Planting date can influence crop growth rate, which is directly related to the crop's competitive ability with weeds. Planting crops before achieving optimum soil temperature can result in poor seed germination, reduced seedling vigor, and delayed establishment. This affects the competitive ability of a crop and can lead to increased weed infestation. Table 1 details minimum temperature requirements for planting major crops in Florida. Planting date also influences the severity and diversity of weeds infesting crops early in the season. Planting crops after most of the earlyseason weeds have germinated can be beneficial because these weeds can be controlled with cultivation or burndown herbicides during field preparation. For example, lower weed density was observed in the North Central United States in late-planted (early June) than in early-planted (mid-May) soybean due to depleted weed seed bank, which led to reduced yield loss (Buhler and Gunsolus 1996). However, planting too late in the season can lead to greater yield loss due to a shorter growing season. Therefore, to determine optimum planting timing, potential yield loss must be weighed against better weed control and improved yield. Overall, the planting date should ensure maximum crop emergence and growth to improve crop competitive ability.

Table 1. Minimum soil temperature $\left({ }^{\circ} \mathrm{F}\right)$ required for germination of agronomic crops.

\begin{tabular}{|l|l|}
\hline Crop & Minimum Soil Temperature at Planting $\left({ }^{\circ} \mathrm{F}\right)$ \\
\hline Corn & $50^{\circ} \mathrm{F}$ at 2 inches depth for 2 consecutive days \\
\hline Cotton & $\begin{array}{l}60^{\circ} \mathrm{F} \text { at root zone; daytime maximum above } 80^{\circ} \mathrm{F} \text { and } \\
\text { nighttime minimum above } 50^{\circ} \mathrm{F} \text { for } 5 \text { consecutive days }\end{array}$ \\
\hline Peanut & $68^{\circ} \mathrm{F}-70^{\circ} \mathrm{F}$ at 4 inches depth for 4 consecutive days \\
\hline Soybean & $50^{\circ} \mathrm{F}$ at 2 inches depth for 2 consecutive days \\
\hline Row S & Pacing \\
\hline
\end{tabular}

Crops are conventionally planted in standard single rows with specific row spacing. Nowadays, twin-rows (where two rows of crops are planted a few inches apart within the same row spacing) are also utilized. Crops planted in narrow single-row spacing or twin-rows have been found to suppress weeds more effectively than those planted in wider row spacings. Twin-row cotton planted 7.5 inches apart in 30 -inch centers provided greater sicklepod and tropical spiderwort control compared to a single-row planting (Stephenson and Brecke 2010). Likewise, the weed-free period (i.e., the time during which crops should be free of weeds to prevent yield loss) can be shorter in narrow row planting compared to wider rows. For example, cotton planted in narrow 21-inch rows required a weed-free period of 6 weeks. However, 10 weeks and 14 weeks were required for 31-inch and 42-inch spacings, respectively (Rogers et al. 1976). Sicklepod and Florida beggarweed biomass increased with an increase in peanut row spacing from 8 inches to 32 inches (Buchanan and Hauser 1980). Weed suppression through adjusted row spacing is attributed to greater light interception and quicker canopy closure by narrow-spaced crops (Figure 1). This reduces weeds' access to resources, thus limiting their competitiveness and growth. However, equipment modifications for planting, harvesting, and other operations as well as increased cost for seed should be considered before adopting the practice.

\section{Seed Quality and Seeding Rate}

An optimum crop stand is very important to obtain maximum weed suppression. Quality seed with higher germination, seedling vigor, and proper treatment/inoculation should be used to ensure optimum crop stand. Moreover, certified crop seed that is free of weed seeds should be used to prevent the introduction of weeds.

Often, higher seeding rates have been found to improve weed suppression by crops. A higher seeding rate can offset in-row plant skips, ensure solid stand, and enhance canopy closure timing, which improves weed suppression. An 
increase in cotton seeding rate from 19,830 plants/acre to 59,894 plants/acre reduced sicklepod size by $70 \%$ and seed production by $72 \%$ (Webster 2007). Higher seeding rates may not necessarily increase yield, but they can reduce weed management costs and contribute to the long-term weed management strategy.

\section{Fertilizer Application}

Fertilizer application can influence the competition between crop and weed. Applying the appropriate fertilizer at an optimal rate and time with a precise method improves the fertilizer use efficiency (FUE). Improved FUE ensures better nutrient acquisition by crops than weeds, resulting in enhanced crop growth and reduced weed growth. For example, band application of a fertilizer (rather than broadcast application) helps early crop establishment and reduces nutrient availability to weeds. Similarly, fertilizer application at appropriate crop growth stages when nutrient requirements are high ensures rapid uptake and reduces loss to weeds.

\section{References}

Buchanan, G. A., and E. W. Hauser. 1980. "Influence of Row Spacing on Competitiveness and Yield of Peanuts (Arachis hypogaea)." Weed Science 28:401-409.

Buhler, D. D., and J. L. Gunsolus. 1996. "Effect of Date of Preplant Tillage and Planting on Weed Populations and Mechanical Weed Control in Soybean (Glycine max)." Weed Science 44:373-379.

Rogers, N. K., G. A. Buchanan, and W. C. Johnson. 1976. "Influence of Row Spacing on Weed Competition with Cotton." Weed Science 24:410-413.

Sankula, S., M. J. VanGessel, and R. R. Mulford. 2004. "Corn Leaf Architecture as a Tool for Weed Management in Two Corn Production Systems." Weed Science 52:1026-1033.

Stephenson, D. O., and B. J. Brecke. 2010. "Weed Management in Single- vs. Twin-Row Cotton (Gossypium hirsutum)." Weed Technology 24:275-280.

Webster, T. M. 2007. "Cotton Row Spacing and Plant Population Affect Weed Seed Production." In World Cotton Research Conference-4, Lubbock, Texas, USA, 10-14 September 2007. International Cotton Advisory Committee (ICAC).
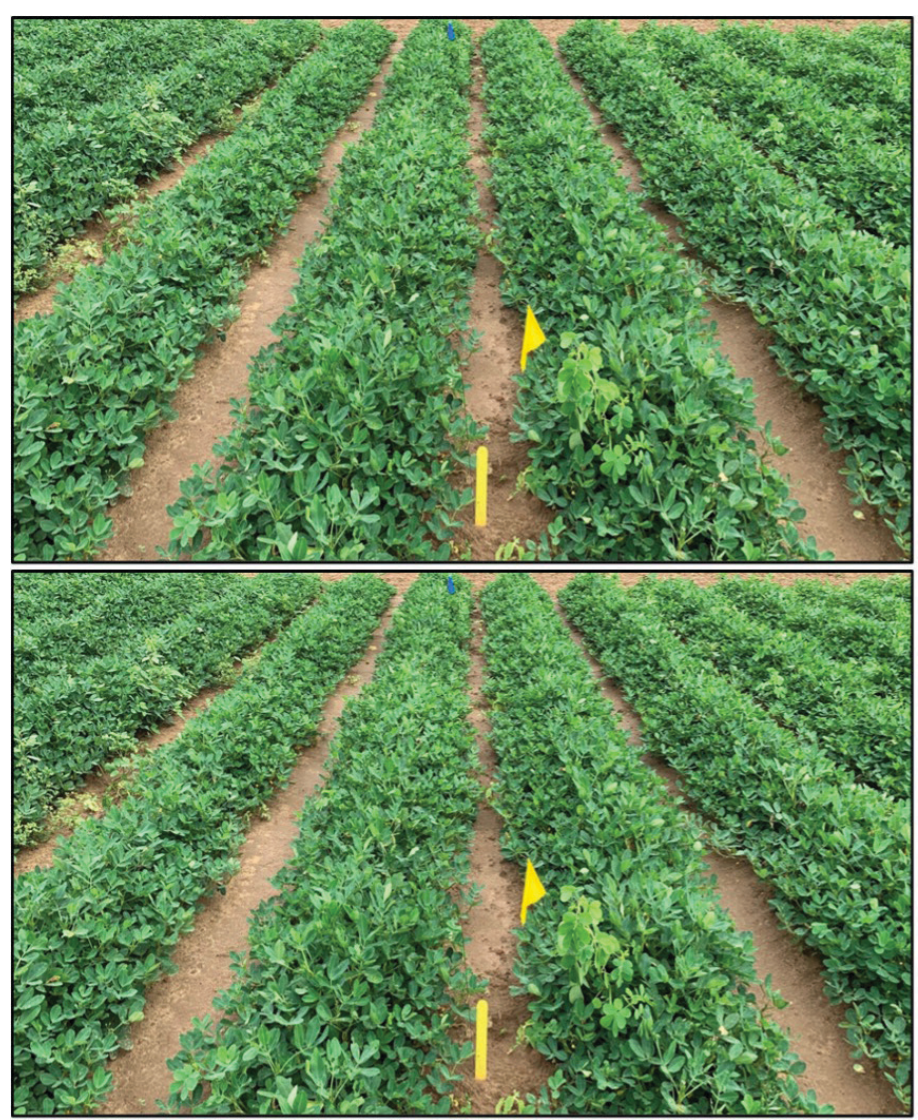

Figure 1. Peanut canopy cover with 5 -inch twin-rows (top) versus 9-inch twin-rows (bottom) at 8 weeks after planting.

Credits: Prasanna Kharel, UF/IFAS 